\title{
KEANEKARAGAMAN HAYATI HUTAN KEMASYARAKATAN UNTUK MENDUKUNG PEMENUHAN KEBUTUHAN GIZI RUMAH TANGGA DI KABUPATEN LAMPUNG BARAT
}

\author{
(Biodiversity of Social Forestry to Support Nutritional Requirement of houshold \\ in West Lampung District)
}

Kelana Indah Susilawati ${ }^{1}$, Yayuk Farida Baliwati ${ }^{2}$, dan Siti Madanijah ${ }^{2}$

\footnotetext{
${ }^{1}$ Program Studi Manajemen Ketahahan Pangan (MKP), Sekolah Pascasarjana, IPB.

${ }^{2}$ Departemen Gizi Masyarakat, Fakultas Ekologi Manusia (FEMA), IPB

Tel: 0251-8628304/8621258; Fax: 0251-8625846/8622276.
}

\begin{abstract}
The Government of West Lampung District issued Social Forestry Program to address forest degradation problem that caused by illegal logging. Therefore, nutritional carrying capacity of Social Forestry was important to be analyzed to understand the advantage of Social Forestry for farmer. The objectives of this research were to 1) analyze the characteristics of farmer household, 2) analyze the commodity diversity of Social Forestry, 3) analyze nutritional carrying capacity of Social Forestry. The sample was 90 Social Forestry's farmer households chosen by using purposive sampling method. The result of the research shows that almost all samples are small family which has elementary schooleducation-level and are Sundanese and Javanese. The average size of land organizing of Social Forestry each household is 1.3 ha ranged 0.25-4 ha. The commodity diversity organized by the farmer household (52.2\%) is included in low category with $\leq 12$ commodities. The average nutritional carrying capacity of Social Forestry is 2754 $\mathrm{kcal} / \mathrm{cap} /$ day. More than half $(67.8 \%)$ of the sample has reach nutritional carrying capacity $\geq 90 \%$ of ideal nutritional requirement.
\end{abstract}

Keywords: biodiversity, nutritional carrying capacity, social forestry.

\section{PENDAHULUAN}

Undang-undang Nomor 7 Tahun 1996 tentang Pangan mengamanatkan bahwa pemerintah bersama masyarakat bertanggung jawab mewujudkan ketahanan pangan. Pemerintah menyelenggarakan pengaturan, pembinaan, pengendalian, dan pengawasan terhadap ketersediaan pangan yang cukup, baik jumlah dan mutunya, aman, bergizi, beragam, merata, dan terjangkau oleh akses masyarakat baik secara ekonomi maupun secara fisik. Masyarakat berperan dalam menyelenggarakan produksi dan penyediaan, perdagangan dan distribusi, serta sebagai konsumen yang berhak memperoleh pangan yang bermutu.

Kabupaten Lampung Barat mempunyai luas hutan sekitar 380092.37 ha atau $76.78 \%$ dari luas wilayah. Terbatasnya luas lahan untuk aktivitas budidaya tanaman, pertumbuhan jumlah penduduk yang semakin meningkat dengan laju pertumbuhan sebesar $1.7 \%$ per tahun, dan banyaknya rumah tangga miskin menyebabkan sebagian masyarakat Lampung Barat merambah kawasan hutan negara untuk melakukan aktivitas budi daya tanaman. Untuk mengatasi permasalahan perambahan kawasan hutan tersebut, Pemerintah Kabupaten Lampung Barat menerapkan kebijakan hutan kemasyarakatan yang bertujuan meningkatkan kesejahteraan masyarakat setempat melalui pemanfaatan sumber daya hutan secara optimal, adil dan berkelanjutan dengan tetap menjaga kelestarian fungsi hutan dan lingkungan hidup. Untuk mengetahui besarnya potensi dan manfaat hutan kemasyarakatan bagi bagi pemenuhan kebutuhan gizi rumah tangga petani salah satunya adalah dengan menghitung keanekaragaman hayati terutama keanekaragaman jenis komoditas yang terdapat pada hutan kemasyarakatan. Penelitian ini bertujuan untuk menganalisis karakteristik rumah tangga petani hutan kemasyarakatan, keanekaragaman jenis komoditas yang berasal dari hutan kemasyarakatan, dan menganalisis daya dukung gizi hutan kemasyarakatan.

\section{METODE PENELITIAN}

\section{Desain dan Tempat Penelitian}

Desain penelitian yang digunakan adalah cross-sectional study pada kelompok tani hu- 
tan kemasyarakatan Kabupaten Lampung Barat. Penentuan lokasi contoh dilakukan secara purposive yaitu terhadap kelompok tani yang telah mendapatkan izin pengelolaan definitif selama 35 tahun sebanyak 5 kelompok tani.

\section{Penarikan Contoh}

Populasi dalam penelitian ini adalah rumah tangga petani hutan kemasyarakatan. Penentuan contoh dilakukan secara acak dengan alokasi proporsional sebanyak 90 rumah tangga.

\section{Jenis dan Cara Pengumpulan Data}

Pengambilan data primer dilakukan dengan pengamatan di lapangan dan wawancara langsung pada setiap rumah tangga contoh. Data sekunder dilakukan dengan mengumpulkan data dari Dinas Kehutanan Kabupaten Lampung Barat dan instansi terkait.

\section{HASIL DAN PEMBAHASAN}

\section{Gambaran Umum Daerah Penelitian}

Secara keseluruhan kelompok tani hutan kemayarakatan di Kabupaten Lampung Barat berjumlah 31 kelompok yang terdiri dari 5 kelompok yang telah mendapat izin Usaha Pengelolaan Hutan Kemasyarakatan (IUPHKm) selama 35 tahun dan 26 kelompok yang telah mendapat izin smentara selama 5 tahun, yaitu Kelompok Tani Bina Wana, Setia Wana Bakti, Mitra Wana Lestari Sejahtera, Rigis Jaya II, dan Tambak Jaya. Sebagian besar hutan kemasyarakatan Kabupaten Lampung Barat berada di hutan lindung Register 45 B dan 44 B wilayah Sumberjaya dan Way Tenong yang merupakan hulu dari Daerah Aliran Sungai (DAS) Way Besai. Topografi wilayah hutan kemasyarakatan adalah berbukit sampai bergunung dengan ketinggian mencapai $1000 \mathrm{~m} \mathrm{dpl}$, curah hujan rata-rata $1600 \mathrm{~mm}$ per tahun, dan suhu ratarata harian sebesar $31^{\circ} \mathrm{C}$.

Luas lahan hutan kemasyarakatan yang dikelola oleh kelima kelompok tani tersebut adalah 1969.96 ha yang terdiri dari areal budidaya 1652.68 dan areal perlindungan 318 ha.

\section{Karakteristik Rumah Tangga}

Berdasarkan hasil analisis, rumah tangga contoh termasuk dalam kategori keluarga kecil (77.8\%) dengan rata-rata jumlah anggota rumah tangga sebanyak 4 orang. Sebagian besar kepala rumahtangga (64.4\%) dan istri (63.3\%) berumur 30-39 tahun. Tingkat pendidikan sebagian besar kepala rumah tangga (54.4\%) dan istri (64.4\%) adalah Sekolah Dasar (SD). Sebanyak $50 \%$ kepala rumah tangga dan $44 \%$ istri berasal dari suku Sunda. Sebagian besar rumah tangga (70\%) mempunyai luas pengelolaan lahan hutan kemasyarakatan $<1.5$ ha dengan rata-rata $1.3 \mathrm{ha} /$ rumah tangga. Pekerjaan sampingan kepala rumah tangga adalah buruh (51\%), mengojek (20\%), beternak (12.2), berdagang (10\%), dan pekerjaan lainnya (6.7\%).

\section{Keanekaragaman Jenis Komoditas}

Secara keseluruhan jumlah jenis komoditas yang berasal dari lahan hutan kemasyarakatan yang merupakan hasil panen petani berjumlah 80 jenis yang terbagi dalam kategori kelompok tanaman pangan, non pangan, dan ternak/ikan yang dikelompokkan ke dalam 8 kelompok pangan sebagaimana disajikan pada Tabel 1. Rata-rata jenis komoditas yang diusahakan setiap rumah tangga adalah 13 jenis.

Tabel 1. Jumlah Jenis Komoditas yang Berasal dari Usaha Hutan Kemasyarakatan

\begin{tabular}{clcc}
\hline No. & Kelompok pangan & Jumlah jenis & $\%$ \\
\hline 1. & Padi-padian & 2 & 2.5 \\
2. & Umbi-umbian & 2 & 2.5 \\
3. & Pangan hewani & 7 & 8.9 \\
4. & Buah/biji berminyak & 3 & 3.8 \\
5. & Kacang-kacangan & 3 & 3.8 \\
6. & Gula & 2 & 2.5 \\
7. & Sayur dan buah & 45 & 57.0 \\
8. & Lain-lain & 8 & 10.1 \\
9. & Non pangan & 8 & 8.9 \\
\hline & Total & 80 & 100 \\
\hline
\end{tabular}

Komoditas yang terdapat pada kelompok padi-padian yaitu padi (Oriza sativa) dan jagung (Zea mays). Produksi padi yang berasal dari lahan hutan kemasyarakatan berasal dari pemanfaatan lahan yang berada di daerah lembah pegunungan dan rawa yang dijadikan lahan persawahan.

Komoditas yang terdapat pada kelompok umbi-umbian dan pangan berpati yaitu singkong (Manihot utilissima) dan biji nangka (Artocarpus heterophyllus). Umbi-umbian biasanya jarang ditanam oleh petani karena tidak sesuai dengan kondisi lingkungan.

Pada kelompok pangan hewani terdapat 7 jenis komoditas yang terdiri dari unggas yaitu angsa (Cygnus sp), ayam (Gallus domestiticus), dan bebek (Amaranthus lividus), ternak ruminansia yaitu kambing (Capra aegagrus hircus), dan ternak ikan mas (Cyprinus carpio). Walaupun usaha ternak tidak secara langsung 
diusahakan oleh para petani di atas lahan hutan kemasyarakatan, tetapi usaha ternak ini dihitung sebagai bagian dari dampak adanya kegiatan hutan kemasyarakatan.

Selanjutnya pada kelompok buah/biji berminyak terdapat 3 jenis komoditas yaitu kelapa (Cocos nucifera), kemiri (Aleurites moluccana), dan melinjo (Gnetum gnemon). Komoditas kemiri dan melinjo biasanya ditanam di sela-sela tanaman kopi dan termasuk kategori tanaman bertajuk tinggi.

Pada kelompok kacang-kacangan juga terdapat 3 jenis komoditas yaitu kapri (Pisum sativum), biji kecipir (Psophocarpus tetragonolobus), dan koro benguk (Mucuna pruriens). Komoditas kacang-kacangan juga ditanam sebagai tanaman selingan atau tanaman pengayaan dan termasuk kategori tanaman tingkat bawah atau tanaman merambat.

Komoditas pada kelompok gula terdapat 2 jenis yaitu gula aren (Arenga pinata) dan madu (Aphis sp.). Gula aren berasal dari pemanfaatan pohon aren yang ada di lahan hutan kemasyarakatan, sedangkan madu berasal dari 2 sumber yaitu madu yang dibudidayakan sendiri oleh petani dan madu yang diambil petani dari hutan berupa madu hutan.

Selanjutnya pada kelompok sayur dan buah terdapat 45 jenis komoditas. Komoditas sayuran terdiri dari sayuran berdaun hijau dan sayuran buah. Sayuran berdaun hijau diantaranya bayam (Amaranthus hybridus), daun katuk (Sauropus androgynus), dan daun labu siam (Sechium edule). Sayuran buah diantaranya nangka muda (Artocarpus heterophyllus), labu siam (Sechium edule), oyong (Luffa acutangula) dan terong (Solanum melongena). Buahbuahan terdiri dari buah sepanjang musim dan buah musiman. Buah yang dapat dipanen sepanjang musim diantaranya pepaya (Carica papaya), pisang (Musa sp.), dan nangka (Artocarpus heterophyllus). Buah musiman diantaranya alpukat (Persea Americana), durian (Durio oxleyanus), dan mangga (Mangifera indica).

Pada kelompok lain-lain (kopi dan bumbu) terdapat 8 jenis komoditas yang terdiri dari bumbu-bumbuan yaitu jahe (Zingiber officinale), kunyit (Curcuma longa), sereh (Cymbopogon nardus), lengkuas (Alpinia galanga), keluwak (Pangium edule), dan lada (Piper nigrum). Selain itu terdapat tanaman kopi (Coffea arabica) yang merupakan komoditas utama pada lahan hutan kemasyarakatan karena telah dibudidayakan sejak pertama kali petani membuka hutan.
Komoditas yang terdapat pada kelompok non pangan berjumlah 8 jenis yaitu rumput pakan ternak (Pennisetum sp.), kakao (Theobroma cacao), pinang (Actinorhytis calapparia), kayu manis (Cinnamomum burmannii), cengkeh (Syzygium aromaticum), bambu (Dendrocalamus sp.), nilam (Pogostemon heyneanus), dan kayu bakar.

Berdasarkan hasil pehitungan diperoleh bahwa rumah tangga yang memiliki keanekaragaman jenis komoditas yang termasuk dalam kategori rendah (<12 jenis) sebanyak $52.2 \%$, sedang (13-24 jenis) sebanyak $38.9 \%$, dan tinggi (>24 jenis) sebanyak $8.9 \%$. Pembagian strata tanaman dikategorikan dalam tajuk tinggi, sedang, dan rendah, sehingga pemanfaatan ruang yang ada dapat maksimal yang berdampak positif terhadap penurunan laju limpasan air hujan sehingga dapat menekan erosi tanah.

\section{Daya Dukung Gizi Hutan Kemasyarakatan}

Daya dukung gizi dalam hal ini daya dukung energi rumah tangga yang berasal dari lahan hutan kemasyarakatan juga dikelompokkan menjadi 8 kelompok pangan dan kelompok non pangan. Besarnya daya dukung energi pada setiap kelompok pangan dapat dilihat pada Tabel 2.

Rata-rata daya dukung gizi hutan kemasyarakatan pada setiap rumah tangga contoh sebesar $2754 \mathrm{kal} / \mathrm{kap} / \mathrm{hr}$, dengan sumbangan tertinggi berasal dari kelompok lain-lain (kopi dan bumbu) sebesar $1875 \mathrm{kal} / \mathrm{kap} / \mathrm{hr}$ atau 68.1\% dan terendah pada kelompok kacangkacangan sebesar $2 \mathrm{kal} / \mathrm{kap} / \mathrm{hr}$ (0.1\%). Jika dibandingkan dengan angka kebutuhan energi (AKE) pada tingkat ketersediaan pangan rumah tangga sebesar $2200 \mathrm{kal} / \mathrm{kap} / \mathrm{hr}$ (WKNPG, 2004), maka rumah tangga yang mempunyai persentase tingkat ketersediaan energi hutan kemasyarakatan pada TKE $\geq 90 \%$ sebanyak $67.8 \%$ dan hanya $32.2 \%$ rumah tangga yang memiliki tingkat ketersediaan energi $<90 \%$. Pada luas lahan < 1.5 ha, keanekaragaman jenis komoditas yang diusahakan oleh rumah tangga petani $61.9 \%$ termasuk dalam kategori rendah. Pada luas lahan 1.5-3 ha, keanekaragaman jenis komoditas yang diusahakan oleh rumah tangga petani $50.0 \%$ termasuk dalam kategori sedang. Demikian pula pada luas lahan $>3$ ha, keanekaragaman jenis komoditas yang diusahakan oleh rumah tangga petani $100 \%$ termasuk dalam kategori sedang. Dengan demikian dapat disimpulkan bahwa semakin luas lahan 
Tabel 2. Rata-rata Daya Dukung Energi Rumah Tangga dari Usaha Hutan Kemasyarakatan

\begin{tabular}{clrrrrr}
\hline \multirow{2}{*}{ No. Kelompok pangan } & \multicolumn{5}{c}{ Daya dukung energi (kal/kap/hr) } \\
\cline { 3 - 7 } & & 276 & 0 & 3058 & 630 & 10.0 \\
\cline { 3 - 6 } 1. & Padi-padian & 7 & 0 & 100 & 23 & 0.3 \\
2. & Umbi-umbian & 46 & 0 & 172 & 48 & 1.7 \\
3. & Pangan hewani & 57 & 0 & 581 & 119 & 2.1 \\
4. & Buah/biji berminyak & 2 & 0 & 103 & 13 & 0.1 \\
5. & Kacang-kacangan & 5 & 0 & 126 & 20 & 0.2 \\
6. & Gula & 128 & 0 & 776 & 163 & 4.6 \\
7. & Sayur dan buah & 1875 & 0 & 6751 & 1291 & 68.1 \\
8. & Lain-lain (kopi dan bumbu) & 357 & 0 & 3700 & 538 & 13.0 \\
9. & Non pangan & 2754 & & & & 100 \\
\hline
\end{tabular}

Tabel 3. Sebaran Rumah Tangga berdasarkan Keanekaragaman Jenis Komoditas terhadap Luas Lahan

\begin{tabular}{|c|c|c|c|c|c|c|c|c|c|c|}
\hline \multirow{3}{*}{ No. } & \multirow{3}{*}{ Kategori luas lahan } & \multicolumn{9}{|c|}{ Keanekaragaman jenis komoditas } \\
\hline & & \multicolumn{3}{|c|}{$\begin{array}{c}\text { Rendah } \\
(\leq 12 \text { jenis })\end{array}$} & \multicolumn{2}{|c|}{$\begin{array}{c}\text { Sedang } \\
(13-24 \text { jenis })\end{array}$} & \multicolumn{2}{|c|}{$\begin{array}{c}\text { Tinggi } \\
(>24 \text { jenis) }\end{array}$} & \multicolumn{2}{|c|}{ Total } \\
\hline & & & $\mathrm{n}$ & $\%$ & $\mathrm{n}$ & $\%$ & $\mathrm{n}$ & $\%$ & $\mathrm{n}$ & $\%$ \\
\hline 1. & $<1.5$ ha (sempit) & & 39 & 61.9 & 21 & 33.3 & 3 & 4.8 & 63 & 100 \\
\hline 2. & $1.5-3$ ha (sedang) & & 8 & 30.8 & 13 & 50.0 & 5 & 19.2 & 26 & 100 \\
\hline \multirow[t]{2}{*}{3.} & $>3$ ha (luas) & & 0 & 0.0 & 1 & 100.0 & 0 & 0.0 & 1 & 100 \\
\hline & Total & 47 & & 52.2 & 35 & 38.9 & 8 & 8.9 & 90 & 100 \\
\hline
\end{tabular}

Tabel 4. Sebaran Rumah Tangga berdasarkan Daya Dukung Gizi terhadap Luas Lahan

\begin{tabular}{|c|c|c|c|c|c|c|c|}
\hline \multirow{3}{*}{ No. } & \multirow{3}{*}{ Kategori luas lahan } & \multicolumn{6}{|c|}{ Tingkat ketersediaan energi } \\
\hline & & \multicolumn{2}{|c|}{ TKE $<90 \%$} & \multicolumn{2}{|c|}{ TKE $\geq 90 \%$} & \multicolumn{2}{|c|}{ Total } \\
\hline & & $\mathrm{n}$ & $\%$ & $\mathrm{n}$ & $\%$ & $\mathbf{n}$ & $\%$ \\
\hline 1. & < 1.5 ha (sempit) & 23 & 36.5 & 40 & 63.5 & 63 & 100 \\
\hline 2. & $1.5-3$ ha (sedang) & 6 & 23.1 & 20 & 76.9 & 26 & 100 \\
\hline \multirow[t]{2}{*}{3.} & $>3$ ha (luas) & 0 & 0.0 & 1 & 100.0 & 1 & 100 \\
\hline & Total & 29 & 32.2 & 61 & 67.8 & 90 & 100 \\
\hline
\end{tabular}

Tabel 5. Sebaran Rumah Tangga berdasarkan Daya Dukung Gizi terhadap Keanekaragaman Jenis

\begin{tabular}{|c|c|c|c|c|c|c|c|}
\hline \multirow{3}{*}{ No. } & \multirow{3}{*}{$\begin{array}{c}\text { Kategori keanekaragaman } \\
\text { jenis komoditas }\end{array}$} & \multicolumn{6}{|c|}{ Tingkat ketersediaan energi } \\
\hline & & \multicolumn{2}{|c|}{ TKE $<90 \%$} & \multicolumn{2}{|c|}{ TKE $\geq 90 \%$} & \multicolumn{2}{|c|}{ Total } \\
\hline & & $\mathrm{n}$ & $\%$ & $\mathrm{n}$ & $\%$ & $\mathrm{n}$ & $\%$ \\
\hline 1. & $\leq 12$ jenis (rendah) & 21 & 44.7 & 26 & 55.3 & 47 & 100 \\
\hline 2. & $13-24$ jenis (sedang) & 7 & 20.0 & 28 & 80.0 & 35 & 100 \\
\hline 3. & $>24$ jenis (tinggi) & 1 & 12.5 & 7 & 87.5 & 8 & 100 \\
\hline & Total & 29 & 32.2 & 61 & 67.8 & 90 & 100 \\
\hline
\end{tabular}

yang diusahakan oleh petani, maka jenis komoditas yang ditanam juga semakin beraneka ragam.

Pada luas lahan $<1.5$ ha, jumlah rumah tangga yang memiliki tingkat ketersediaan energi $\geq 90 \%$ lebih banyak (63.5\%) dibandingkan dengan rumah tangga yang memiliki tingkat ketersediaan energi $<90 \%$ (36.5\%). Pada luas lahan 1.5-3 ha, persentase rumah tangga yang memiliki tingkat ketersediaan energi $\geq$ $90 \%$ sebanyak $76.9 \%$. Demikian halnya pada luas lahan $>3$ ha, persentase rumah tangga yang memiliki tingkat ketersediaan energi $\geq 90 \%$ se- banyak $100 \%$. Hal ini menandakan bahwa semakin luas lahan yang dikelola oleh petani, maka semakin besar daya dukung gizi yang diperoleh untuk mencukupi kebutuhan rumah tangga.

Untuk mencapai tingkat ketersediaan energi $\geq 90 \%$, pada tingkat keanekaragaman rendah sebanyak $55.3 \%$ rumah tangga, pada tingkat keanekaragaman sedang sebanyak $80.0 \%$ rumah tangga, dan pada tingkat keanekaragaman tinggi sebanyak $87.5 \%$ rumah tangga. Hal ini menggambarkan bahwa semakin beranekaragam jenis tanaman, maka keterse- 
diaan energi yang dihasilkan juga semakin besar. Untuk memperoleh keseimbangan manfaat ekonomi dan ekologi dari hutan kemasyarakatan dengan tingkat ketersediaan energi $\geq 90 \%$ ukuran yang optimal adalah pada luas lahan 1.5-3 ha dengan keanekaragaman jenis komoditas yang diusahakan sebanyak 13-24 jenis.

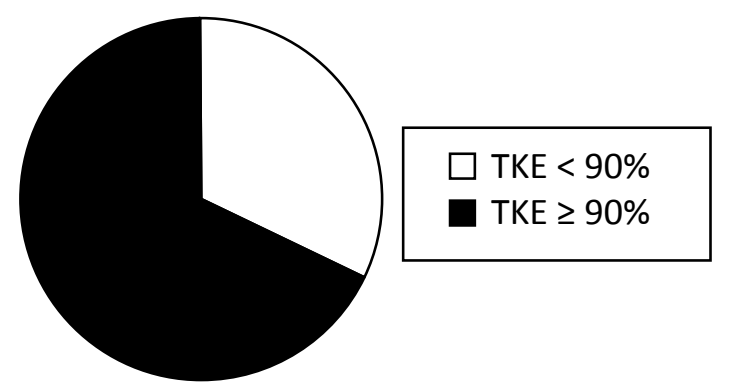

Gambar 1. Sebaran Rumah Tangga berdasarkan Daya Dukung Gizi

Jika dianalisis lebih lanjut, komposisi jenis tanaman yang ditanam berdasarkan keragaman tajuk tanaman (tajuk tinggi, sedang, dan rendah) adalah $35.9 \%$ jenis tanaman bertajuk tinggi, 28.8\% jenis tanaman bertajuk sedang, dan 35.3\% jenis tanaman bertajuk rendah (Gambar 2).

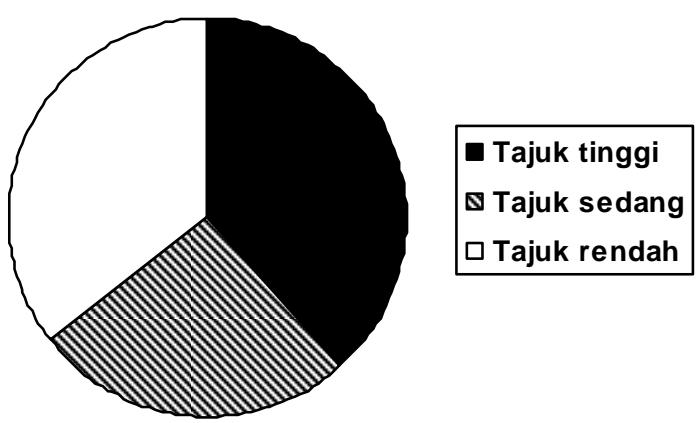

Gambar 2. Komposisi Jumlah Jenis Tanaman untuk Mencapai TKE $\geq 90 \%$

Menurut Morgan (1989), kerapatan tanaman akan mempengaruhi panjang lintasan aliran permukaan dan luasan lahan yang tertutup. Semakin rapat tanaman yang ada di permukaan lahan maka semakin kecil energi hujan yang sampai ke tanah, sehingga semakin kecil kemungkinan terjadinya erosi. Berdasarkan hasil uji coba dan perhitungan yang dilakukan Utomo (2001), sistem agroforestry (kebun campuran) terbukti telah memberi hasil lebih tinggi dibandingkan dengan sistem monokultur, dengan memasukkan tanaman buah-buahan, tanaman pohon, pakan ternak, dan usaha ternak. Dari segi konservasi sistem agroforesty kompleks sangat menguntungkan karena bukan saja dapat menekan kerusakan tanah, tetapi bahkan dapat memperbaiki sifat tanah dan memperkaya hara sehingga dapat meningkatkan kesuburan dan produktifitas tanah.

\section{KESIMPULAN}

Rumah tangga petani hutan kemasyarakatan $\mathbf{7 7 . 8 \%}$ merupakan rumah tangga kecil, umur kepala rumah tangga dan umur istri berkisar antara 30-39 tahun dan termasuk usia produktif, dengan rata-rata pendidikan kepala rumah tangga dan istri 7 tahun (setingkat SLTP), suku kepala rumah tangga dan istri sebagian besar Sunda.

Keanekaragaman jenis komoditas yang diusahakan petani pada kegiatan hutan kemasyarakatan termasuk dalam kategori keanekaragaman rendah dengan rata-rata 13 jenis komoditas pada setiap rumah tangga. Komposisi jenis tanaman untuk mencapai daya dukung energi dengan tingkat kecukupan $\geq 90 \%$ adalah $35.9 \%$ jenis tanaman tajuk tinggi, $28.8 \%$ jenis tanaman tajuk sedang, dan $35.3 \%$ jenis tanaman tajuk rendah.

Rata-rata daya dukung gizi hutan kemasyarakatan sebesar $2754 \mathrm{kal} / \mathrm{kap} / \mathrm{hr}$. Daya dukung tertinggi terdapat pada kelompok lainlain (kopi dan bumbu) sebesar 1875 $\mathrm{kal} / \mathrm{kap} / \mathrm{hr}$ (68.1\%) dan terendah pada kelompok kacang-kacangan sebesar 2 $\mathrm{kal} / \mathrm{kap} / \mathrm{hr}$ (0.1\%). Sebesar $67.8 \%$ rumah tangga petani telah mencapai tingkat ketersediaan energi yang berasal dari hutan kemasyarakatan $\geq 90 \%$.

\section{DAFTAR PUSTAKA}

Morgan RPC. (1989). Soil Erotion and Conservation. Longman Group, Hongkong.

Utomo WH. 2005. Agroforestry: Hidup Layak Berkesinambungan pada Lahan Sempit. Dalam: Krisnamurthi, B., A.B.S. Dwi, dan Kriswantriyono (Eds.), Prosiding Seminar: Tekanan Penduduk, Degradasi Lingkungan dan Ketahanan Pangan. Kerjasama Pusat Studi Pembangunan Lembaga Penelitian IPB, Proyek Koordinasi Kelembagaan Ketahanan Pangan dan Badan Bimas Ketahanan Pangan Departemen Pertanian, Jakarta. 